\title{
PENGARUH LINGKUNGAN TERHADAP PERILAKU MANUSIA: STUDI TERHADAP PERILAKU PENONTON BIOSKOP
}

Fathul Lubabin Nuqul

\begin{abstract}
Human being always makes interaction with his environment. Both influence each other. The environment forces human to use certain behavior, and on the other hand human also influences the arrangement of environment. This influencing each other becomes vicious circle which happens in every element of human life, it does so in entertainment, in this case film or cinema. This research wants to see behavior of human being (moviegoer) linked with environmental setting

This research is conducted in the Movies Permata in Jogjakarta. The method of this research is qualitative. Data is taken from interview with seven informant and direct observation. The result of research, in general, indicates that pollution, temperature, setting of area, and also existence of others influences behavior of audience (moviegoer) in the building.
\end{abstract}

Keywords: Environment, cinema, movies, and behavior.

Manusia ditengah-tengah kesibukannya banyak dilalui dengan rutinitas yang melelahkan, sehingga pada titik tertentu individu tersebut akan mengalami kejenuhan. Bila hal ini terjadi maka individu tersebut akan membutuhkan hiburan atau rekreasi untuk melepas energi-energi yang menumpuk yang tidak digunakan lagi. Ada beberapa macam hiburan yang ditawarkan pada saat ini mulai dari yang bernuansa trdisisonal sampai yang bernuansa modern seperti live musik maupun film baik yang diputar di televisi maupun yang diputar di gedung bioskop.

Khusus untuk bioskop, pada saat ini merupakan media hiburan yang menarik iuntuk dikaji, mengingat bioskop dulunya sekitar tahun 80-an merupakan primadona hiburan untuk berbagai lapisan masyarakat. Pada puncak kejayaannya bioskop terbagi menjadi beberapa kelas. Kelas yang paling tinggi adalah kelas studio Cineplex 21 th dengan harga tiket yang relatif mahal mampu membuat penonton merasa nyaman dengan film yang relatif baru, ruangan yang ber-AC, sound system yang canggih sehingga menghasilkan yang jernih dan kursi yang empuk.

Kelas di bawah studio 21th, merupakan gedung bioskop yang tertutup tanpa pendingin udara, biasanya hanya dengan kipas angin. Sedangkan kelas yang paling sederhada adalah bioskop layar dengan uang 300-1000 rupiah saja penonton bisa menikmati pertunjukan film.

Seiring dengan perkembangan teknologi hiburan, masyarakat mempunyai banyak alternatif pilihan kemana haris mencari hiburan terutama film. Bioskop pada saat ini mulai tergeser dengan keberadaan telivisi dan Video Compact Disk (VCD) 
yang konon lebih menjanjikan kenyamanan karena bisa dinikmati kapan saja, tanpa harus keluar rumah, berdesak-desakan antri tiket dengan penonton yang lain.

Meskipun demikian keberadaan bioskop tidak sepenuhnya ditinggalkan oleh penonton, karena ada hal yang tak diperoleh dari menonton fim di rumah. Di bioskop orang bisa berinteraksi dengan orang lain atau ada tantangan tersendiri dalam bioskop dalam memperoleh privasinya. Sayangnya, seiring dengan penurunan jumlah penonton, pengelolaan dan perawatan bioskop pun juga asal-asalan. Banyak fasilitas yang rusak, fentilasi udara yang tidak berfungsi dengan baik dan penataan kursi yang sembarangan. Setting lingkungan yang seperti ini akan mempengaruhi motivasi dan perilaku penonton di dalam bioskop.

Dari uraian di atas muncul pertanyaan bagaimana pola perilaku penonton bioskop dalam kaitannya dengan lingkungan. Untuk itu penelitian ini ber tujuan untuk menjawab permasalahan, apa yang dilakukan oleh penonton bioskop? Bagaimana Pengaruh lingkungan terhadap penonton bioskop? Motivasi apa yang mendasari orang datang ke bioskop? Dan apakah bioskop dianggap oleh penonton sebagai tempat penghilang stres atau sebagai stresor baru?.

\section{Teori Psikologi Lingkungan}

Manusia dan lingkungan merupakan dua faktor yang terus berinteraksi dan terus saling mempengaruhi, perilaku manusia bisa merubah lingkungan misalnya manusia menebang hutan, sebaliknya lingkungan sangat berpengaruh terhadap bagaimana manusia berperilaku. Ada 4 cara bagaimana lingkungan mempengaruhi manusia. ${ }^{1}$ Lingkungan menghalangi perilaku. Sehubungan dengan hal itu kita juga membatasi apa yang hendak kita lakukan, misalnya tembok di kamar kita membatasi kemana kita melangkahkan kaki atau anak yang tinggal diperkotaan tidak pernah melihat laut, sungai, hutan kurang mempunyai rasa menghargai terhadap alam

1. Lingkungan mengundang dan mendatangkan perilaku. Misalnya ketika di masjid kita diharuskan untuk tenang

2. Lingkungan membentuk diri. Perilaku yang dibatasi oleh lingkungan dapat menjadi bagian yang menetap dalam diri yang menentukan arah perkembangan kepribadian di masa yang akan datang.

3. Lingkungan mempengaruhi citra diri. Contohnya seorang raja akan menganggap bahwa dirinya sangat berharga dengan "membaca" pesan kemewahan yang ada di istananya, atau juga seoprang gembel merasa betapa rendah dirinya jika dia "menginterpretasikan" keadaan rumahnya yang kumuh dan kotor.

Adapun lingkungan fisik dan non fisik yang mempengaruhi perilaku manusia antara lain adalah:

\section{Temperatur}

Hubungan antara temperatur lingkungan dengan fungsi fisik dan psikis manusia sangat komplek. Di Indonesia mempunyai dua musim yakni kemarau dan penghujan. Pada musim kemarau, temperatur sangat panas yang disebabkan oleh keadaan matahari yang tepat di atas katulistiwa dan suhunya mencapai 28-31 derajat celsius. Untuk mencapai kenyamanan fisik maka temperatur yang ideal adalah 23 derajat 
celsius, kelembaban 50-60\% dan kecepatan angin 2-3 m/detik. ${ }^{2}$ Suhu yang tidak nyaman atau yang terlalu panas akan mempengaruhi manusia baik secara fisik maupun psikis, seperti suhu tubuh manusia akan naik, kerja pembuluh darah akan meningkat, aliran darah yang deras dan tubuh menjadi berkeringat. Detak jantung akan meningkat jika seseorang bekerja dalam suhu yang tinggi, penguapan keringat dingin di muka kulit dan darah mengalir ke permukaan sehingga kulit menjadi kemerah-merahan ${ }^{3}$. Jika seseorang berada dalam suhu yang tinggi secara terus menerus dapat menurunkan volume darah sehingga mengakibatkan keringat keluar, pembuluh darah membesar, akibatnya tekanan darah akan menurun otak kekurangan oksigen dan orang akan pingsan, kejang-kejang atau bahkan koma. Akhirnya jika terus-menerus dalam waktu yang lama pada waktu yang lama maka seseorang bisa mati.

Demikian halnya pengaruh suhu yang tinggi terhadap psikis, dari penelitian yang telah dilakukan ternyata orang yang berada dalam ruang yang panas tidak begitu tertarik kepada orang lain dibandingkan dengan orang yang bekerja dalam suhu yang sedang-sedang saja. Ditemukan juga bahwa ada korelasi yang positif antara temperatur yang tinggi dengan agresifitas. Sehingga temperatur yang tinggi mempengaruhi kerusuhan di jalan. hal ini juga menjawab kenapa kerusuhan banyak terjadi di siang hari.

\section{Polusi Udara}

Polusi udara menurut Veitch \& Arkkelin ${ }^{4}$ mempunyai banyak sumber seperti :

a. Carbon Dioksida (CO2) berbentuk gas yang tak berwarna, berasal dari metabolisme binatang termasuk manusia yang dikeluarkan lewat pernafasan.

b. Corbon Monoksida (CO) berasal dari pembakaran yang tidak sempurna misalnya asap kendaraan bermotor. $\mathrm{CO}$ ini bisa mengakibatkan masalah kesehatan walau dalam keadaan konsentrasi yang rendah seperti gangguan pendengaran, Parkinson, epilepsi, kelelahan, sakit kepala, kerusakan memori dan bahkan sintomp-sintomp psikotik yang lain.

c. Sulfur dan Nitrogen Oksides (SO2 \& NO2) berasal dari pembakaran fosil fual sebanyak $45 \%$ dan sisanya dari peleburan bijih, akibat fisik dari zat ini adalah danggun sistem pernafasan sedangkan akibat psikologisnya belum diketahui.

d. Asap rokok, Lewtas ${ }^{5}$ menyatakan bahwa asap tembakau (rokok) sebagai kontributor utama pada polusi udara di ruangan. Asap yang dihasilkan oleh tembakau mempunyai kepekatan yang tinggi dar beberapa partikel yang biasa disebut dengan Tar dan asap yang meliputi Nitrogen, oksigen, CO2, dan CO dalam konsentrasi yang lebih kecil. Asap rokok yang di identifikasikan mengandung 4.720 senyawa nitrates dalam tembakau yang membantu untuk pengembangan Hydrogen Cyanida (HCN), Nitric Oxide (NO) Nitrogen Dioksida. Asap rokok juga dianggap sebagai penyebab utama penyakit jantung koroner dan kanker paru-paru.

Secara umum apapun penyebab polusi, kecenderungannya akan merimbas pada peningkatan temperatur udara. Secara psikologis temperatur tersebut akan 
berpengaruh negatif, jika berasa di atas ambang kenyamanan yang bisa diterima oleh tubuh manusia.

\section{Kebisingan}

Kebisingan merupakan salah satu sumber stress yang berasal dari suara yang tidak diinginkan seperti suara gaduh, suara kendaraan atau suara musik yang keras.berdasarkan survey yang dilakukan di Austria dan Swedia suara akan menggganggu bila berada pada 40-45 dB (baca: Desibel) pada siang hari dan 35-40 $\mathrm{dB}$ pada malam hari. ${ }^{6}$. Beberapa penelitian juga membuktikan bahwa kebisingan juga berpengaruh negatif terhadap perilaku pribadi menyebabkan kejengkelan, mengurangi daya konsentrasi seseorang. Selain itu juga kebisingan bisa sebagai pemicu perilaku agresif bagi mereka yang mempunyai karakter agresif ${ }^{7}$

Reaksi fisik terhadap kebisingan menurut $\operatorname{Rosen}^{8}$ adalah pembuluh darah berkerut, pupil mata membesar, berkedip, menahan nafas (membuat nafas sesak) ketegangan otot syaraf, gelisah, mudah marah dan cemas dan yang paling fatal adalah kerusakan organ pendengaran secara permanen.

Penelitian dari Lebo \& Olipant ${ }^{9}$ menemukan tentang orang-orang yang berada di dalam bar dan klap malam yang di dalamnya terdapat suara-suara dengan intensitas tinggi antara 100-120 dB dengan waktu lebih dari setengah jam, ditemukan bahwa 60\% dari anak muda 18-19 tahun memperlihatkan kehilangan pendengaran pada saat kegaduhan terjadi, mereka mengalami keadaan patalogis pada mekanisme reseptor. Efek tentang kegaduhan musik juga dilaporkan Agres \& Huglis ${ }^{10}$ dalam penelitian yang menunjukkan bahwa ketajaman visual seseorang terganggu dengan kehadiran musik yang keras.

\section{Kepadatan (Crowding)}

Kita sering dibingungkan dengan definisi antara crowding dan density. Density adalah fisik dari ruangan yang terbatas yang diukur dengan berbandingan antara banyaknya orang dengan luas ruangan, sedangkan crowding adalah bagian dari perasaan yang menetap yang didapat melalui persepsi pada ruang. Jadi perbedaan antara density dengan crowding adalah jika density bersifat obyektif dan crowding bersifat subyektif pada tiap orang.

Crowding mempunyai mempunyai pengaruh terhadap kesehatan dan fisik seperti meningkatnya tekanan darah. Pengaruhnya terhadap psikis juga banyak misalnya berkurangnya kemampuan menyerap informasi, menurunkan kemampuan kerja jika orang tersebut dalam keadaan kerja dan mengganggu istirahat jika orang tersebut istirahat.

Crowding secara psikis mengurangi daya tarik terhadap orang lain selain itu juga akan mengurangi kontrol individu dalam interaksi dengan orang lain. Dalam realitanya banyaknya kejahatan dan perkelaihan di daerah yang kumuh karena pada daerah tersebut tingkat crowding-nya cukup tinggi.

\section{Teritori, Privasi dan Jarak Personal}

\section{Teritori}


Teritori adalah perilaku mahluk hidup dengan karakternya dalam mengklaim suatu wilayah dari gangguan untuk kepentingan kelompok maupun spesiesnya. ${ }^{11}$ Dalam usahanya untuk mempertahankan teritori, manusia tanda-tanda seperti pagar dan tempat lain sebagai tanda tempat itu ada pemiliknya, sedangkan pada hewan dengan zat kimiawi seperti urin.

Fungsi dari teritori adalah untuk mempertegas kepemilikan atas suatu yang bersifat pribadi. Keuntungan psikologis dalam menempati teritori adalah orang akan merasa nyaman, aman dan rileks. Keuntungan lain adalah adanya perasaan mengakar dan perasaan mengenal.

Jenis teritori pada manusia menurut Hecmanm ${ }^{12}$ ada tiga :

a. Teritori primer: misalnya rumah, merupakan pemilika yang bersifat eksklusif dengan jangka waktu yang permanen dan berada dalam pengawasan yang bersifat total. Pemilikan dimaksudkan untuk menghindari pemaksaan dari pihak luar. Terotorialitas ini merupakan perluasan dari self, berkaitan dengan identitas diri dan harga diri seseorang. Jadi lebih bersifat pernyataan tentang sifat pribadi diri kepada orang lain.

b. Teritori sekunder: didasarkan pada beberapa tingka kepemilikan. Wilayah ini tidak eksklusif terhadap hal milik, artinya seseorang tidak memiliki kontrol penuh atas wilayah ini dikarenakan kepemilikannya bersifat sementara, misalnya kursi kelas, jadi tidak diperlukan aturan-aturan informal yang dipublikasikan. Dengan demikian untuk menyatakan ketidak senangan terhadap orang lain atas kepemilikan ini tidak menggunakan norma atau pemaksaan yang secara eksplisit.

c. Teritori umum: merupakan kepemilikan yang bersifat umum, misalnya taman, restoran, pantai dan bioskop. Kepemilikan ini didasarkan atas siapa yang datang duluan dan sifatnya hanya sementara sampai si pengguna kepemilikan ini selesai dengan kepentinganya. Ada hal-hal tertentu dalam teritori umum ini yang menyediakan lokasi-lokasi kepemilikan barang pribadi yang biasanya dihormati oleh orang lain.

\section{Privasi}

Privasi menurut Altman adalah proses batas interpersonal yang dipakai individu untuk mengatur kontak dengan orang lain ${ }^{13}$. Privasi juga merupakan proses yang melibatkan dinamika yang saling mempengaruhi antara kekuatan lawan yang mencari interaksi dengan yang membatasi interaksi, membatasi sikap keterbukaan atau mengambil sikap tertutup. Privasi juga merupakan optimalisasi kontak, artinya sejauhmana kepuasan diri dicapai melalui kontak atau tanpa kontak.

Westin ${ }^{14}$ membedakan 4 macam privasi:

a. solitude : keinginan menyendiri.

b. intimacy: keinginan untuk intim (dekat) dengan orang tertentu saja dan jauh dari orang lain.

c. anonimaty : keinginan menyembunyikan identitas diri.

d. reserve: menciptakan batas psikologis atau keinginan untuk tidak mengungkapkan diri terlalu banyak pada orang lain.

\section{Jarak Personal}


Respon sikap manusia bila sedang berinteraksi dalam ruang dengan menggambarkan bagaimana perasaan yang ditimbulkan oleh masing-masing pihak sehubungan dengan situasi dan kondisi setempat, lingkungan budaya dan permasalahan yang dihadapi. Dengan memperlihatkan inter-relasi dengan aring lain dan kondisi ruangan yang digunakan maka akan terjadi perbedaan-perbedaan sikap jarak dalam tatap muka (interaction distance) sebagai berikut: ${ }^{15}$ :

a. Intimate distance (jarak intim) : yaitu berbicara antara dua orang atau lebih yang sudah sangat intim seprti meraka yang sedang berpacaran, berbicara dengan anak-anak atau antara keluarga sendiri dengan jarak $45 \mathrm{~cm}$ kecuali pada tempattempat tertentu misalnya pada valuator (lift) atau kendaraan umum, pada intimate distance penjagaan jarak tidak mungkin dihidarkan namun demikian masing-masing pihak akan selalu menjaga jarak dan teritori.

b. Personal distance (jarak pribadi) yaitu seperti jarak antara kursi tamu dengan kursi pemilik sejauh $60-100 \mathrm{~cm}$ dalam suatu ruang pribadi yang tidak semua orang bisa memasukinya.

c. Social distance (jarak sosial) yaitu jarak interaksi publik dalam suatu peremuan sejauh $150 \mathrm{~cm}-3$ meter, sedangkan dalam gedung semi publik bisa mencapai 2-3 meter. Pada ruang rapat yang terbatas jumlah pesertanya dianjurkan agar satu sama lain berjarak 4 meter agar tiap pembicara bisa mendengar jelas.

d. Public distance (jarak umum) jarak ini biasanya terjadi di convention hall atau ruang kuliah yang jaraknya 20-30 meter.

d. Proxemics distance, jarak ini terjadi pada massa yang tidak saling mengenal seperti masa kampanye atau penonton sepak bola yang tidak saling kenal namun tetap berinteraksi.

\section{Desain dan Perilaku}

Dalam proses perencanaan tata ruang, manusia merupakan tokoh utama yang akan berperan menempati dan menggunakan tata ruang, oleh karena itu harus mendapatkan perhatian khusus dan segala sesuatu yang berkenaan dengan masalah perilaku manusia (behaviour) dengan kata lain behaviour adalah pengertian yang mempelajari tentang tingkah laku manusia.

Banyak sekali perencanaan yang tidak didasarkan atas perilaku orang yang akan memakainya, maka apabila perencanaan tersebut selesai dilaksanakan pada akhirnya tidak dirasakan sebagai suatu kenikmatan oleh pemakainya. Banyak yang harus dipenuhi mulai menyangkut hobi, pekerjaan, kegiatan atau semua hal yang menyangkut aspek perilaku manusia.

Manusia adalah kesatuan materi dan non materi dari berbagai unsur yang tak dapat dibagi-bagi, untuk itu ada beberapa faktor yang perlu diperhatikan berkaitan dengan manusia dan tata ruang :

$\Psi$ Manusia sesungguhnya merupakan materi yang berohani, yang membuat manusia berbeda dengan mahluk hidup lainnya adalah materi rohani tersebut.

$\Psi$ Manusia juga sebagai mahluk biologis, karena menusia juga mempunyai unsur alam seperti mahluk hidup lainnya. 
$\Psi$ Sebagai non materi manusia mempunyai unsur yang disebut dengan jiwa dan roh kemudian kita sebut dengan mahluk psikis.

$\Psi$ Sepanjang hidup manusia merupakan anggota suatu kelompok masyarakat, manusia menyadari bahwa tanpa hubungan dengan manusia lain tidak akan lengkap oleh karena itu dalam kodratnya ia akan selalu bersifat sosial saling berhubungan dalam satu kekeluargaan, kekerabatan dan kemasyarakatan.

$\Psi$ Hakekat manusia adalah dalam satu kebersamaan

Dengan memperhatikan faktor di atas maka tidak dapat dipungkiri bahwa manusia adalah mahluk psikis biologis dan sosial. Manusia akan melewatkan sebagian hidupnya dalam ruangan dan mengatur diri mereka sendiri secara naluriah dalam ruangan tersebut.

Manusia adalah mahluk sosial yang perlu berhubungan dengan orang lain didalam melakukan aktivitas sehari-hari, tetapi manusia juga individu-individu yang membutuhkan privasi dalam melakukan kegiatan-kegiatan tertentu, manusia memerlukan penataan ruang yang dapat menjamin privasinya.

Kebutuhan inilah yang menyebabkan ruang dibedakan menjadi sosiofugal dan sosiopetal. $^{16}$ Ruang Sosiofugal adalah ruang yang penetaannya cenderung memisahkan masing-masing individu sehingga tercipta suasana yang lebih privat. Penataan seperti ini misalnya terjadi pada ruang tunggu, terminal, bioskop atau perpustakaan, orang mengunjungi perpustakaan untuk memebaca buku dan orang yang datang ke gedung bioskop untuk menonton film. Dalam keadaan tersebut orang tidak mengharapkan untuk berhubungan denagn orang lain karena pada umumnya orang tersebut tidak saling mengenal. Ruangan fisik sosiofugal dibentuk dengan membuat sekat pada dinding dan mengatur kursi yang berderet bersebelahan, dengan penataan yang seperti ini orang cenderung untuk mengabaikan orang lain. ${ }^{17}$

Ruang sosiopetal pengaturan ruangan ini cenderung untuk menyatukan individu sehingga tercipta interaksi sosial. Hal ini dapat dilihat pada ruang keluarga, ruang sidang dimana biasanya kursi di tata melingkar atau berhadapan.

\section{Keputusan Menonton}

Dalam memahami perilaku penionton bioskop, interaklsi antara gedung biokop dengan dan manusia lain sebagai unsur dari lingkungan akan mempengaruhi perilaku penonton mulai dari proses pencarian informasi, keputusan untuk menonton pada film atau gedung bioskop tertentu, sampai pengulangan untuk menonton kembali. Dalam hal ini Sukirno ${ }^{18}$ mengemukan tentang tahapan-tahapan dalam keputusan untuk menonton bioskop yang merupakan adopsi dari keputusan untuk membeli yang dikemukakan oleh Kotler ${ }^{19}$ yang terdiri dari beberapa tahapan :

1. Penjelasan masalah: adanya keinginan individu untuk mencapai tujuan misalnya untuk memenuhi kebutuhan akan hiburan.

2. Pencarian informasi : setelah tahu apa yang dibutuhkan dalam memenuhi kebutuhan akan hiburan, individu akan mencari informasi dari pihak lain misalnya koran atau teman . 
3. Evaluasi alternatif : dari informasi yang didapat individu mempunyai banyak alterntif yang dipilih atau dengan kata lain ada beberapa bioskop yang ada, mana yang akan dipilih.

4. Keputusan membeli (menonton): arti bberapa alternatif maka pengabilan keputuisan adalah hal yang terpenting, pengambilan keputusan ini sedikit banyak dipengaruhi oleh proses informasi yang di dapat. Dalam memutuskan individu akan melihat dari sudut pandang dirinya (unsur suyektif) terhadap jenis film, waktu, keadaan lingkungan dan keberadan orang lain apa sudah sesuai dengan seleranya atau bukan.

5. Perilaku purna menonton: dalam perilaku sehabis menonton ini individu akan mengevaluasai keputusannya dengan membandingkan apa yang telah diperoleh. Jika memang dalam menonton individu memperoleh kepuasan maka akan membentuk kesan yang positif dan sebaliknya jika tidak maka akan muncul kecenderungan untuk tidak mengulanginya.

Dengan demikian proses dari awal individu berperilaku dalam hal ini perilaku menonton sampai akhirnya dia mengulanginya lagi, melibatkan banyak faktor internal (persepsi) maupun faktor eksternal (lingkungan fisik maupun non fisik). Secara internal apakah menonton telah memuaskan kebutuhannya. Secara ekternal apakah lingkunganbaik secara fisik maupun lingkungan sosial mendukung apa yang di inginkan.

\section{Metode Penelitian}

Penelitian ini dilakukan di gedung bioskop Permata yang terletak di Jl Sultan Agung Jogjakarta. Jenis penelitian yang digunakan adalah penelitian deskriptif kualitatif Dalam penelitian ini data diambil dengan menggunakan metode depth interview dan observasi partisipan (peneliti ikut terlibat dalam perilaku bersama dengan informan di lapangan).

Pada penelitian ini melibatkan 7 orang subyek (informan) yang diambil secara acak dengan mempertimbangkan usia (dewasa) informan terdiridari penonton $(\%$ orang) dan karyawan bioskop ( 2 orang). Sedangkan observasi dilakukan selama 3 minggu.

\section{Hasil Penelitian Dan Pembahasan}

\section{Deskripsi Lokasi Penelitian}

Penelitian ini dilakukan di gedung bisokop Permata yang terletak di Jalan Sultan Agung Jogjakarta. Gedung bioskop ini merupakan gedug bioskop kelas rendah hal ini terlihat dari tarif masuk sekitar 1500-2000 rupiah. Gedung bioskop permata termasuk yang tertua yang telah dibangun sejak jaman penjajahan Belanda.

Pada gedung bioskop ini mempunyai dua ruang utama yaitu ruang Lobi dan Ruang Pemutaran film. Runga lobi mempunyai beberapa bagian antara lain loket karcis, tempat bermain ding dong, 22 buah kursi dengan dua model tatanan (16 buah dengan tatanan sosiofugal dan 6 buah dengan tatanan sosiopetal) dan dinding yang ditempati untuk menempelkan poster. 


\section{Pengaruh Polusi Udara, Temperatur dan Kebisingan Terhadap Perilaku Penonton}

Dari investigasi peneliti sumber polusi udara yang ada di gedung bioskop Permata secara garis besar bisa dibedakan menjadi dua. Pertama polusi yang berasal dari kendaraan bermotor dan yang kedua polusi berasal dari penonton terutama dari asap rokok. Seperti yang dikemukakan oleh oleh Veitch \& Arkkelin $^{20}$ bahwa perokok ada dua macam yaitu perokok aktif (mainstream) yaitu perokok itu sendiri dan perokok aktif (sidestream) yaitu orang yang menghisap asap rokok yang dikeluarkan oleh perokok.

Perokok aktif biasanya mempunyai perasaan senang terhadap perilaku merokoknya. Sebaliknya penonton yang non perokok merasa terganggu dengan asap rokok, hal ini bisa dilihat dari perilakunya yang mengibas-ngibaskan tangan atau sesuatu untuk menghalau asap.

Dari perilaku tersebut penonton yang non perokok (sidestream) sesungguhnya mempunyai sikap yang negatif tetapi tidak bisa berbuat banyak karena "norma sosial" yang ada pada bioskop Permata mengijinkan seorang penonton untuk merokok. "Norma" ini bisa dilihat dari ruangan yang tak ber-AC dan tak ada tanda larangan merokok serta tersedianya asbak, membuat perokok merasa mendapat legitimasi dan leluasa menikmati rokoknya. Bahkan sebagian informan mengatakan bahwa diperbolehkannya merokok pada saat menonton membuat daya tarik tersendiri untuk menonton di bioskop permata dari pada bioskop lainnya.

Perilaku merokok seperti ini merupakan perilaku diperkuat oleh lingkungan sehingga sulit bagi orang yang tak suka terhadap asap rokok untuk menghentikannya karena lingkungan bioskop "menciptakan" perilaku merokok.

Kaitannya dengan temperatur atau suhu, polusi memberi konstribusi yang besar terhadap peningkatan temperatur ruangan baik itu yang berasal dari kendaraan bermotor maupun dari asap rokok sama mempunyai pengaruh yang kuat. Temperatur ruangan semakin meningkat jika ada banyak orang dalam sebuah ruangan. begitu pula dalam ruangan bioskop Permata yang fentilasi udaranya kurang bagus dan tanpa pendingin udara $(\mathrm{AC})$ membuat suhu semakin meningkat terutama jika penonton sedang ramai. Temperatur ruangan akan cenderung memanas (menurut informan bisa mencapai 32 derajat celsius).

Efek dari temperatur atau suhu yang tinggi terhadap penonton akan cenderung mempengaruhi perilaku. Yang paling tampak adalah perilaku untuk mengatasi kegerahan misalnya dengan minum atau kipas-kipas. Namun secara teoritis suhu yang panas akan mempengaruhi metabolisme tubuh membuat tubuh cepat lelah dan berkeringat, secara psikis akan mempengaruhi juga pada sikap prososial dan peningkatan agresifitas ${ }^{21}$. Begitu juga di juga dengan perilaku penonton bioskop, diduga bahwa sikap acuh dengan penonton lain juga di picu oleh meningkatnya suhu udara di dalam gedung bioskop.

Dengan demikian polusi yang diakibatkan sendiri oleh beberapa penonton akan mempengaruhi lingkungan terutama temperatur udara yang juga akibatnya akan 
mempengaruhi perilaku dan kenyamanan dalam beraktivitas yang dalam hal ini menonton film.

Selain polusi udara, ada polusi suara atau yang lebih di kenal dengan kebisingan. Kebisingan diakibatkan oleh suara keras yang diluar ambang penerimaan pendengaran manusia. Di gedung bioskop Permata berasal dari suara keras berasal dari sound system. Namun kebanyakan informan tidak menganggap hal itu sebagai suatu yang bising sehingga suara keras tersebut tidak direspon secara negatif.

Dari fenomena tersebut dapat disimpulkan bahwa suara keras tidak selalu dianggap bising hal ini ada dua faktor. Pertama suara keras tersebut memang dinginkan oleh individu yang bersangkutan seperti halnya penonton bioskop. Kedua karena adanya adaptasi. Orang yang sering kali mendengar suara keras dengan intensitas yang teratur, lama-kelamaan akan menganggap suara tersebut sebagai hal yang biasa.

\section{Pengaruh Ruangan Terhadap Perilaku Penonton.}

\section{Ruang lobi}

Seperti di ketahui bahwa penataan tempat duduk di ruangan lobi ada dua macam yaitu sosiofugal dan sosiopetal. Penataan ini mempengaruhi perilaku penonton, kebanyakan penonton mengambil tempat duduk dengan penataan sosiofugal, karena penetaan ini individu cenderung mengabaikan orang lain. Hal ini bisa dimaknai bahwa keinginan untuk berinteraksi dengan orang lain pada penonton bioskop cukup rendah.

Selain penataan kursi, di ruang lobi juga ada tempat penjualan tiket. Perilaku penonton pada saat membeli tiket sering mengalami kekacauan terutama pada hari libur dimana pengunjung mengalami peningkatan. Berkaitan dengan perilaku membeli karcis ini adalah teori bahwa antrian tercipta bertujuan untuk memperlancar urusan.

Pada penonton bioskop Permata antrian dalam membeli tiket tidak terjadi hal ini di karenakan tidak adanya tempat yang represesntatif untuk berderet antri. Di depan loket ada tembok tang jaraknya hanya 1,5 meter, sehingga tak memungkinkan melakukan antrian selain itu juga tidak adanya kesefahaman dari penonton untuk memperlancar ujuan mereka. Ini karena antar penonton belum saling mengenal. Penonton yang hadir teori bisa di kategorikan sebagai massa yang mudah sekali melakukan kerusuhan. Perilaku antrian jika tak dikendalihan sangat mungkin memunculkan pericuhan.

\section{Ruang Pemutaran Film}

Setelah diobservasi perilaku saat menonton, dimulai dari penonton memasuki ruang pemutaran film. Pada saat inilah adaptasi dimulai khususnya terhadap pencahayaan yang jauh lebih gelap daripada ruangan yang ada di luar. Sehingga sebagian besar penonton awalnya mengalami kesulitan mencari tempat duduk, tapi permasalahan ini sedikit teratasi dengan bantuan lampu senter yang disediakan oleh pengelola gedung bioskop. Perilaku penonon ini menunjukkan perlunya pencahayaan yang cukup dalam mendukung aktivitasnya. 
Dalam memilih tempat duduk di ruang pemutaran film umumnya penonton cenderung mengambil tempat yang mendukung privasi dan kenyamanan dalam menonton yang paling sering di pilih menurut informan adalah tempat duduk paling belakang atau yang paling atas. Menurut informan jika duduk di kursi yang paling depan membuat mata cepat lelah.

Tidak semua penonton yang berada di ruang pemutaran film memperhatikan film yang diputar. Ada beberapa penonton khususnya yang berpasangan melakukan aktivitas yang tak ada kaitannya dengan menonton film. Menurut keterangan informan dan observasi banyak penonton yang berpacaran di dalam gedung bioskop. Alasan mereka, di ruangan yang gelap akan merasa mempunyai privasi, tidak termonitor oleh penonton yang lain. Bahkan menurut informan ada yang sampai melakukan hubungan yang terlalu jauh dan tidak menyadari kalau filmnya sudah selesai, hal ini di ketahui oleh kru gedung bioskop ketika lampu dinyalakan.

\section{Interaksi Penonton Dengan Penonton Yang Lain}

Dalam Interaksi dengan penonton yang lain di gedung bioskop, pada umunnya individu (penonton) cenderung memilih tempat yang berjauhan dengan penonton yang dikenalnya dan cenderung mendekat pada orang yang di kenalnya. Gejala interaksi seperti ini seperti merupakan privasi yang berjenis intimacy (keinginan untuk hanya dengan orang tertentu saja) bagi mereka yang datang berpasangan atau juga bisa merupakan solitude (keinginan untuk menyendiri) bagi yang datang sendiri.

Selain itu penonton mengambil jarak sosial dengan orang yang belum dikenalnya antara 120-210 cm (social distance) sadangkan bagi mereka yang berpasangan mengambil jarak sekitar 0-45 (intimacy distance). Sehingga interaksi antar penonton dalam kerumunan atau di tempat umum mempunyai dua pola jika belum saling mengenal akan saling menjauh dan jika telah saling mengenal akan saling mendekat hal ini untuk mencari rasa aman di tempat umum.

\section{Perilaku Saat Menonton}

Pada umumnya informan mengatakan bahwa motivasi mereka menonton di Bioskop Permata ada dua hal. Pertama, karena harga karcis murah. Kedua karena film yang di putar di bioskop tersebut merupakan film yang tidak mungkin ada di TV (bertema seks). Namun sebenarnya mereka juga kecewa jika terlalu banyak sensor dalam film. Meskipun demikian mereka mengaku tak kapok untuk datang kembali untuk menonton karena mereka menganggap bahwa bioskop merupakan sarana mereka menghilangkan stres dari pekerjaan sehari-hari.

Penonton umumnya menonton film dengan melakukan aktivitas yang lain misalnya dengan makan makanan ringan atau dengan merokok. Sering kali juga, penonton terkait secara emosi dengan alur film yang sedang diputar. Gejala ini bisa di lihat dari gejala perilaku penonton yang muncul seperti berteriak, memaki-maki atau dengan celetukan-celetukan. Perilaku penonton seperti ini menunjukkan bahwa perilaku sosial manusia tidak hanya di sebabkan interaksi dengan manusia lain saja tetapi juga dengan dunia virtual seperti film, televisi atau internet

Penonton juga tak segan-segan untuk meninggalkan tempat pemutaran film, jika film yang ditontonnya kurang menarik banyak penonton yang merasa tertipu dengan 
poster, sementara film yang diputar tidak sesuai dengan harapan. Sering terlihat juga penonton melampiaskan kekecewaannya menjadi agresivitas verbal dengan berteriakteriak. Agresifitas ini selain didasari oleh kekecewaan terhadap film yang kurang menarik dan sering putus-putus juga dikarenakan oleh faktor lingkungan seperi suhu yang panas (telah dijelaskan di atas)

\section{Kesimpulan}

Dari hasil penelitian tersebut di atas secara garis besar dapat disimpulkan bahwa lingkuangan, baik fisik maupun sosial akan mempengaruhi kinerja fisik dan psikis seseorang yang juga akan sangat berpengaruh terhadap perilaku di tempat tersebut, baik perilaku secara individual maupun perilaku secara sosial.

\section{Catatan Akhir}

1. Calhoun, J.F dan Acocella, J. R, Psikologi Tentang Penyesuaian dan Hubungan Kemanusian. (Semarang: IKIP Press, 1990),

2 Suptandar, J. P, Desain Interior, (Jakarta: PT Djambatan, 1999),

3 Veitch, R. and Arkkelin, D, Environment Psychology. (London: Printice Hall, Inc, 1995),

4 Ibid

5 Ibid

6 Suptandar, J. P, Desain Interior,

7 Calhoun, J.F dan Acocella, Psikologi Tentang Penyesuaian dan Hubungan Kemanusian, 8 Veitch, R. and Arkkelin, Environment Psychology,

9 Ibid

${ }^{10} \mathrm{Ibid}$

${ }^{11}$ Ibid

${ }^{12}$ Ibid

${ }^{13}$ Ibid

${ }^{14} \mathrm{Ibid}$

${ }^{15}$ Forsyith, D. RAn Introduction to Group Dynamic. (California: Books/Cole Publishing Company, 1983),

${ }^{16}$ Suptandar, Desain Interior,

${ }^{17}$ Calhoun dan Acocella, Psikologi Tentang Penyesuaian,

${ }^{18}$ Sukirno, I., "Sikap Penonton Terhadap Fasilitas Dan Jenis Film Yang Diputar Pada

Berbagai Gedung Bioskop Di Kotamadya Yogyakarta", (Yogyakarta, Pascasarjana Universitas Gadjah Mada, Tesis, 1990),

${ }^{19}$ Kotler Philip, Management Marketing, Analysis, Planning, Implementation and Control. (New Jersey: Prentice Hall, 1988),

${ }^{20}$ Veitch, R. and Arkkelin, Environment Psycholog,

${ }^{21}$ Ibid

\section{DAFTAR PUSTAKA}


Calhoun, J.F dan Acocella, J. R.. Psikologi Tentang Penyesuaian dan Hubungan Kemanusian. Semarang: IKIP Press, 1990

Forsyith, D. R. An Introduction to Group Dynamic. California: Books/Cole Publishing Company, 1983

Kotler Philip, Management Marketing, Analysis, Planning, Implementation and Control. New Jersey: Prentice Hall, 1988

Sukirno, I.,. Sikap Penonton Terhadap Fasilitas Dan Jenis Film Yang Diputar Pada Berbagai Gedung Bioskop Di Kotamadya Yogyakarta, Tesis. Pascasarjana Universitas Gadjah Mada Yogyakarta, 1990

Suptandar, J. P. Desain Interior. Jakarta: PT Djambatan, 1999

Veitch, R. and Arkkelin, D, Environment Psychology. London: Printice Hall, Inc, 1995 